\title{
Tumor necrosis factor- $\alpha$ promotes airway mucus hypersecretion by repressing miR-146a-5p and miR-134-5p levels in human airway epithelial cells
}

\author{
Hui-Ting Fu ${ }^{1 \#}$, Yan Zhang ${ }^{2 \#}$, Ping Zhang ${ }^{1}$, Huan Wu ${ }^{1}$, Xuan-Qiu Sun ${ }^{1}$, Shu-Yang Shen ${ }^{1}$, Dan-Bo Dou ${ }^{1 \wedge}$ \\ ${ }^{1}$ Department of Traditional Medicine, Shuguang Hospital affiliated to Shanghai University of Traditional Chinese Medicine, Shanghai, China; \\ ${ }^{2}$ Department of Ultrasound, Shuguang Hospital affiliated to Shanghai University of Traditional Chinese Medicine, Shanghai, China \\ Contributions: (I) Conception and design: DB Dou, HT Fu; (II) Administrative support: DB Dou; (III) Provision of study materials or patients: \\ HT Fu; (IV) Collection and assembly of data: HT Fu, Y Zhang, P Zhang, H Wu; (V) Data analysis and interpretation: XQ Sun, SY Shen; \\ (VI) Manuscript writing: All authors; (VII) Final approval of manuscript: All authors. \\ \#These authors contributed equally to this work. \\ Correspondence to: Dan-Bo Dou. No. 528, Zhangheng Rd., Shanghai 201203, China. Email: doudanbo@shutcm.edu.cn.
}

Background: Airway mucus acts as an indispensable protective component of innate immune response against invading pathogens. However, airway mucus hypersecretion, largely consisting of mucin 5 AC (MUC5AC), is the leading cause of airflow obstruction and airway hyperresponsiveness that contributes to chronic obstructive pulmonary disease (COPD). MicroRNAs (miRNAs) are frequently dysregulated in the pathogenesis of COPD, but the definite role of miRNAs in airway mucus hypersecretion is not well understood.

Methods: A cell model of mucus hypersecretion was established in $16 \mathrm{HBE}$ cells by treatment with TNF- $\alpha$. Cell viability and apoptosis were assessed using cell counting kit-8 (CCK-8) and flow cytometry, respectively. The aberrant expression of miR-146a-5p and miR-134-5p was assayed in TNF- $\alpha$-treated $16 \mathrm{HBE}$ cells, and the effect of miR-146a-5p and miR-134-5p on regulating MUC5AC expression was evaluated using quantitative real-time PCR (qPCR) and Western blot analysis.

Results: TNF- $\alpha$ treatment resulted in a significant decrease of cell viability, and increase of cell apoptosis and MUC5AC expression in 16HBE cells. Additionally, the expression of miR-134-5p and miR-146a-5p was markedly decreased in the cell model. Importantly, forced expression of miR-134-5p and miR-146a-5p significantly repressed TNF- $\alpha$-induced upregulation of MUC5AC. Mechanistically, although miR-134-5p did not affect $16 \mathrm{HBE}$ cells viability and apoptosis, miR-134-5p partially blocked TNF- $\alpha$-induced MUC5AC expression by inhibiting the activation of NF- $\kappa \mathrm{B}$ signaling. On the other hand, miR-146a-5p enhanced cell viability and reduced cell apoptosis. miR-146a-5p also repressed TNF- $\alpha$-induced MUC5AC expression by inhibiting p38 MAPK (mitogen-activated protein kinase) signaling activation.

Conclusions: The current data demonstrated that both miR-134-5p and miR-146a-5p conferred protection against TNF- $\alpha$-induced mucus hypersecretion through repressing NF- $\kappa \mathrm{B}$ and p38 MAPK signaling, indicating that miR-134-5p and miR-146a-5p may serve as the biomarker for COPD.

Keywords: miR-134-5p; miR-146a-5p; chronic obstructive pulmonary disease (COPD); mucin 5AC (MUC5AC); $\mathrm{NF}-\kappa \mathrm{B}$

Submitted Dec 08, 2020. Accepted for publication Jul 14, 2021.

doi: $10.21037 /$ tcr-20-3375

View this article at: https://dx.doi.org/10.21037/tcr-20-3375

$\wedge$ ORCID: 0000-0001-5069-6294. 


\section{Introduction}

Chronic obstructive pulmonary disease (COPD) is an airway obstructive pulmonary disease characterized by persistent airflow limitation (1). That air pollution and occupational exposures to dust and fumes are risk factors to induce COPD, and cigarette smoke is the main cause of COPD (2). The pathogenesis of COPD mainly includes airway inflammation, oxidative stress, protease/antiprotease imbalance, emphysema, and airway mucus secretion (3-5). In clinical treatment, glucocorticoids and bronchodilators are used to alleviate the symptoms of COPD but produce limited clinical efficacy $(6,7)$. Mucus hypersecretion is associated with shortness of breath, impaired mucociliary clearance, infection, and chronic cough $(8,9)$. Currently, the underlying mechanisms leading mucus hypersecretion are not well understood.

miRNAs are a kind of small non-coding RNAs, which play an important role in regulating gene expression (10). miRNAs are involved in various biological processes and in human diseases (11). Mounting evidence has indicated that miRNAs are closely related to the occurrence and development of COPD (12). Various miRNAs are differentially expressed in serum, sputum, and lung of COPD patients (13). For instance, the level of miR-15b is accumulated in COPD lung tissues, and miR-15b targets SMAD7 that participates in transforming growth factor $\beta$ (TGF- $\beta$ ) signaling pathway to regulate COPD progression (14). In plasma and lung tissue from COPD, the level of miR-29b is reduced, and miR29b regulates airway inflammation in COPD by targeting bromodomain protein 4 (BRD4) (15).

Tasena et al. has demonstrated that 20 differentially expressed miRNAs are associated with mucus hypersecretion in COPD (12). Out of the 20 miRNAs, miR-134-5p and miR-146a-5p are lower expressed in COPD patients, and are crucial miRNAs associated with several mucus hypersecretion-correlated potential targets (12). miR-134$5 \mathrm{p}$ is a potential marker for the clinical diagnose of acute exacerbation of COPD (16). Down-regulated miR-146a-5p is involved in the pathogenesis of COPD through inducing more proinflammatory phenotype (17-19). Given that NF$\kappa \mathrm{B}$ signaling acts as critical roles in facilitating mucin 5AC (MUC5AC) expression (20) and miR-134-5p possesses a potential effect of regulating $\mathrm{NF}-\kappa \mathrm{B}$ activation, we thus investigated whether miR-134-5p repressed MUC5AC expression by inhibiting NF- $\mathrm{\kappa B}$ signaling in cell model of airway mucus hypersecretion. We also explored the role and underlying mechanism of miR-146a-5p in regulating
MUC5AC expression. Although several inflammatory cytokines (IL-1 $\beta$, IL-5, IL-13, etc.) have been demonstrated to produce MUC5AC expression in vitro and in vivo $(21,22)$, the effect of TNF- $\alpha$ on airway mucus hypersecretion has not been widely investigated, and thus TNF- $\alpha$ was used to establish the cell model of airway mucus hypersecretion.

We present the following article in accordance with the MDAR checklist (available at https://dx.doi.org/10.21037/ tcr-20-3375).

\section{Methods}

\section{Cell culture and TNF- $\alpha$ treatment}

The human bronchial epithelial cells (16HBE), provided from ScienCell (Santiago, California, USA), were maintained in RPMI 1640 medium (Solarbio, Beijing, China) with $10 \%$ fetal bovine serum (FBS) and $1 \%$ penicillin/streptomycin and kept at temperature of $37^{\circ} \mathrm{C}$ in an incubator with $5 \% \mathrm{CO}_{2} .16 \mathrm{HBE}$ cells were treated with TNF- $\alpha$ (R\&D Systems, Minneapolis, MN, USA; $10 \mathrm{ng} / \mathrm{mL}$ ) for $24 \mathrm{~h}$ to construct airway mucus hypersecretion cell model according to previous reports $(23,24)$ and our preliminary experiments (Figure S1).

\section{Flow cytometry}

$16 \mathrm{HBE}$ cell apoptosis was determined using Flow cytometry with an Annexin V-FITC/PI Apoptosis Detection Kit (BD Biosciences, San Jose, CA, USA). $16 \mathrm{HBE}$ cells $\left(1 \times 10^{6}\right.$ cells $\left./ \mathrm{mL}\right)$ were treated with TNF- $\alpha$ $(10 \mathrm{ng} / \mathrm{mL})$ for $24 \mathrm{~h}$ in the presence of indicated reagents. After washing with PBS, the cells were re-suspended with $500 \mu \mathrm{L} 1 \times$ binding buffer and stained with $5 \mu \mathrm{L}$ of Annexin V conjugated to FITC and $5 \mu \mathrm{L}$ PI for $15 \mathrm{~min}$. Cytometry data was analyzed using FlowJo software (Treestar, Ashland, OR).

\section{miRNA mimics}

miR-134-5p mimics (UGUGACUGGUUGACCAGAGG GG), miR-146a-5p mimic (UGAGAACUGAAUUCCAU GGGUU), and miRNA control (miRcont) were synthesized by Shanghai GenePharma Co., Ltd (Shanghai, China). 16HBE cells were transfected with $40 \mathrm{nmol} / \mathrm{L}$ miR-134-5p, miR-146a-5p mimic, or miRcont with Lipofectamine 2000 (Thermo Fisher Scientific, MA, USA) and Opti-MEMreduced serum medium (Solarbio) according to previous 
Table 1 Oligonucleotide sequences used in the study

\begin{tabular}{|c|c|}
\hline Primer & Sequences $\left(5^{\prime}-3^{\prime}\right)$ \\
\hline hsa-miR-146a-5p-RT & GTCGTATCCAGTGCAGGGTCCGAGGTATTCGCACTGGATACGACAACCC \\
\hline hsa-miR-146a-5p-F & CGGCTGAGAACTGAATTCCAT \\
\hline hsa-miR-146a-5p-R & GTGCAGGGTCCGAGGT \\
\hline hsa-miR-134-5p-RT & GTCGTATCCAGTGCAGGGTCCGAGGTATTCGCACTGGATACGACCCCC \\
\hline hsa-miR-134-5p-F & UGUGACUGGUUGACCAGA \\
\hline hsa-miR-134-5p-R & GTGCAGGGTCCGAGGT \\
\hline MUC5AC-F & СТССТСТСССАСААСАССААG \\
\hline U6-R & AACGCTTCACGAATTTGCGT \\
\hline $18 S-F$ & AGGAATTCCCAGTAAGTGCG \\
\hline 18S-R & GCCTCACTAAACCATCCAA \\
\hline
\end{tabular}

reports and our preliminary experiments. Forty-eight h post-transfection later, cells were collected and qPCR was used to assess transfection efficiency.

\section{Cell viability assay}

Cell viability was evaluated with the Cell Counting Kit8 (CCK-8, Solarbio). In brief, 16HBE cells were plated in 96-well plates $\left(2 \times 10^{4}\right.$ cells/well $)$ for $24 \mathrm{~h}$ at $37^{\circ} \mathrm{C}$. Then, $16 \mathrm{HBE}$ cells were treated with TNF- $\alpha(10 \mathrm{ng} / \mathrm{mL})$ for different time (0, 24, 48, and $72 \mathrm{~h}) .10 \mu \mathrm{L} \mathrm{CCK}-8$ solution was added and incubated for another $3.5 \mathrm{~h}$. The absorbance (value) at $450 \mathrm{~nm}$ was measured by a scanning microplate reader (Bio-Rad, Hercules, CA, USA).

\section{Quantitative real-time PCR (qPCR)}

Total RNA from 16HBE cells was isolated using TRIzol kit (Takara, Japan). Reverse transcription for complementary DNA (cDNA) synthesis was performed with Transcriptor First Strand cDNA Synthesis Kits (Roche, Basel, Switzerland). qPCR was carried out with SYBR Green qRT-PCR Master Mix (Enzyme, Nanjing, China) on the 7500 fast real-time PCR system (ThermoFisher Scientific, Waltham, MA, USA) as previously described (25). U6 and $18 \mathrm{~S}$ was used as internal control for miRNA and mRNA, respectively. Relative RNA expression was analyzed using $2^{-\Delta \Delta \mathrm{Ct}}$ method and relative primer sequences were listed in Table 1.

\section{Western blot analysis}

Total protein from 16HBE cells was extracted using RIPA lysis buffer (Elabscience, Wuhan, China). After protein concentrations were determined by BCA Protein Assay Kit (Takara, Japan), equal amount of protein for each sample was resolved with SDS-PAGE (10\%) and then immobilized onto PVDF membranes (Roche, Basel, Switzerland). The membranes were soaked in $5 \%$ non-fat dried milk in PBS and incubated with antibodies against MUC5AC $(1: 1,000$, ab24071, Abcam), p65 (0.5 $\mathrm{gg} / \mathrm{mL}$, ab16502, Abcam), Lamin B1 $(0.1 \mu \mathrm{g} / \mathrm{mL}$, ab16048, Abcam), and $\beta$-actin $\left(1: 5,000 ;\right.$ ab8226, Abcam) overnight at $4{ }^{\circ} \mathrm{C}$ respectively, and then incubation with corresponding secondary antibody at room temperature for $60 \mathrm{~min}$. The blots were revealed with an ECL kit (Abcam) and analyzed by Image Software (NIH, Bethesda, MD, USA).

\section{Statistical analysis}

All data were reported as mean \pm standard deviation (SD). Statistical analyses were performed by SPSS 13.0 (SPSS 
A

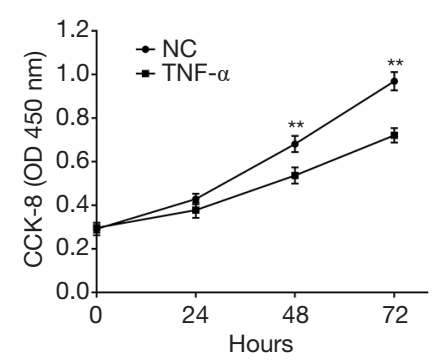

D

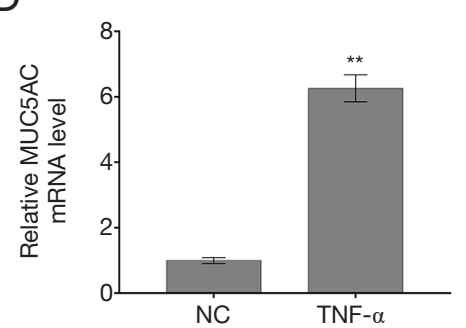

G

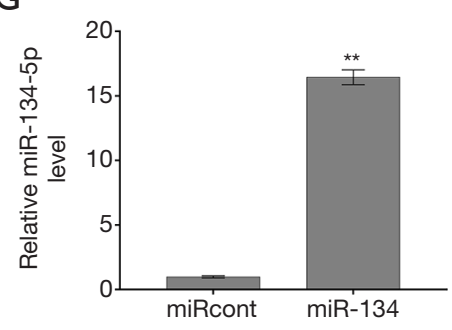

B

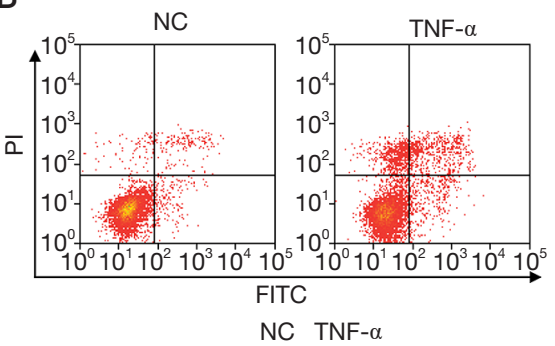

E

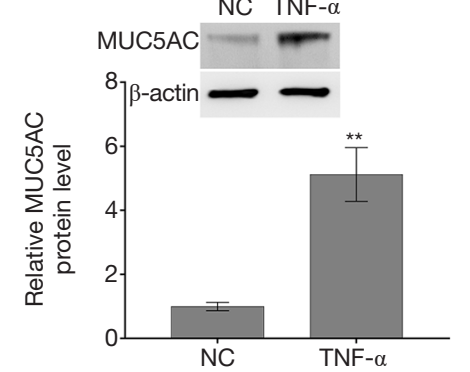

$\mathrm{H}$

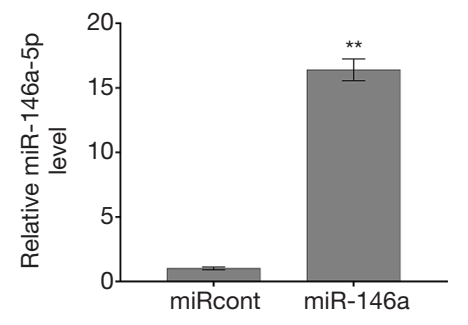

C

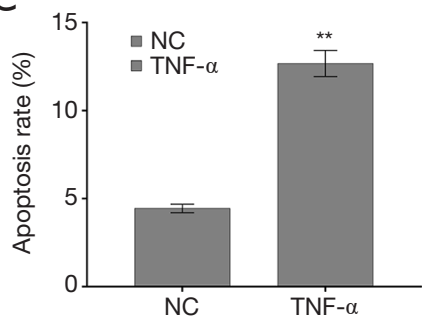

F

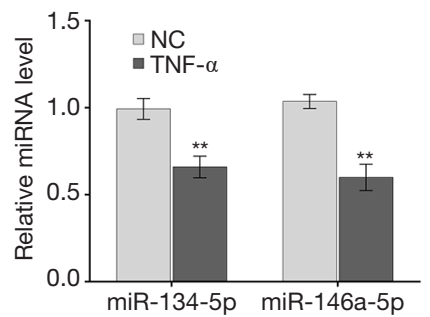

I

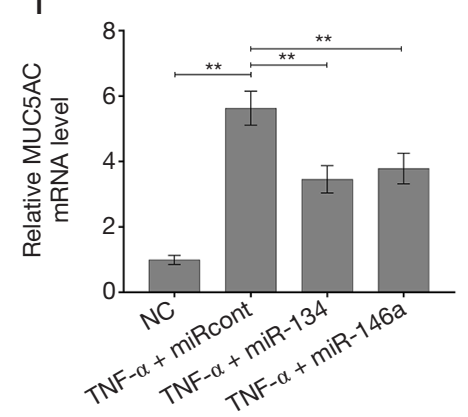

Figure $1 \mathrm{TNF}-\alpha$ repressed 16HBE cell viability and increased MUC5AC expression. (A) Cell viability was assessed in 16HBE cells after treatment with TNF- $\alpha(10 \mathrm{ng} / \mathrm{mL})$ for $0,24,48$ or $72 \mathrm{~h}$ using the CCK-8 assay. (B) $16 \mathrm{HBE}$ cells were treated with TNF- $\alpha(10 \mathrm{ng} / \mathrm{mL})$ for $24 \mathrm{~h}$, and cell apoptosis was assessed using flow cytometry. The proportion of apoptotic cells was showed in (C). Values are presented as mean $\pm \mathrm{SD}$ of three independent experiments. The mRNA (D) and protein (E) expression levels of MUC5AC were assessed in 16HBE cells treated with or without TNF- $\alpha(10 \mathrm{ng} / \mathrm{mL})$ for $24 \mathrm{~h}$. (F) The expression level of miR-134-5p (miR-134) and miR-146a-5p (miR-146a) was assessed in $16 \mathrm{HBE}$ cells in the presence or absence of TNF- $\alpha(10 \mathrm{ng} / \mathrm{mL})$. The expression level of miR-134 $(\mathrm{G})$ and miR-146a $(\mathrm{H})$ was assessed in 16HBE cells treated with miR-134 mimics and miR-146a mimics, respectively. (I) The mRNA level of MUC5AC was assessed in TNF- $\alpha$-treated $16 \mathrm{HBE}$ cells in the presence of miR-134 or miR-146a. ${ }^{* *}, \mathrm{P}<0.01$.

Inc., Chicago, IL, USA). Differences between two groups were calculated with two-tailed student's $t$-test, or ANOVA followed by the Scheffé test for multiple groups. $\mathrm{P}<0.05$ was considered statistically significant.

\section{Results}

TNF- $\alpha$ treatment increased MUC5AC expression, and repressed miR-134-5p (miR-134) and miR-146a-5p (miR-146a) expression in 16HBE cells

To explore the mechanisms underlying TNF- $\alpha$-induced airway mucus hypersecretion in vitro, 16HBE cells were treated with TNF- $\alpha(10 \mathrm{ng} / \mathrm{mL})$ for $24 \mathrm{~h}$ to establish mucus hypersecretion cell model. CCK-8 assay was used to assess $16 \mathrm{HBE}$ cells viability after TNF- $\alpha$ treatment. As shown in Figure $1 A$, TNF- $\alpha$ treatment significantly repressed $16 \mathrm{HBE}$ cells viability compared to the control. The role of TNF- $\alpha$ in regulating $16 \mathrm{HBE}$ cells apoptosis was then assessed through Flow cytometry analysis. Figure $1 B, C$ showed that the apoptosis rate of $16 \mathrm{HBE}$ cells was increased after TNF- $\alpha$ treatment. As expected, TNF- $\alpha$ treatment increased the mRNA and protein level of MUC5AC in 16HBE cells 
(Figure 1D,E). The previous studies have demonstrated that miR-134-5p (miR-134) and miR-146a-5p (miR-146a) are involved in mucus hypersecretion in COPD (12,16-19). To explore the association of TNF- $\alpha$-induced MUC5AC expression with these miRNAs, we first assessed whether TNF- $\alpha$ regulated the expression of these miRNAs. As shown in Figure 1F, the expression of miR-134 and miR$146 \mathrm{a}$ were significantly decreased in $16 \mathrm{HBE}$ cells after TNF- $\alpha$ treatment. More important, forced expression of miR-134 or miR-146a alleviated TNF- $\alpha$-induced increase of MUC5AC (Figure 1G,H,I). These data suggest that TNF- $\alpha$ increased MUC5AC expression, at least in part by repressing miR-134 and miR-146a expression.

\section{miR-134 partially blocked TNF-a-induced MUC5AC expression by repressing $N F-\kappa B$ activation}

Figure $2 A$ further showed that forced expression of miR134 and miR-146a inhibited MUC5AC expression more effectively than miR-134 or miR-146a overexpression separately. Then we investigated the role of miR-134 and miR-146a in regulating TNF- $\alpha$-induced MUC5AC expression, respectively. As shown in Figure $2 B, C, D$, miR134 did not affect TNF- $\alpha$-regulated $16 \mathrm{HBE}$ cells viability and apoptosis. However, miR-134 partially blocked TNF$\alpha$-induced MUC5AC expression (Figure 2E). Given the crucial role of NF- $\mathrm{\kappa B}$ signaling in MUC5AC expression, we next whether miR-134 repressed TNF- $\alpha$-induced activation of NF- $\mathrm{KB}$ signaling. The results from Western blot analysis showed that miR-134 markedly inhibited TNF- $\alpha$-induced nuclear translocation of NF- $\mathrm{KBp} 65$ (Figure $2 F$ ), indicating that miR-134 blocked TNF- $\alpha$-induced MUC5AC expression, at least in part by repressing $\mathrm{NF}-\kappa \mathrm{B}$ signaling activation.

\section{miR-146a partially blocked TNF- $\alpha$-induced MUC5AC expression by repressing $\mathrm{p} 38 \mathrm{MAPK}$ activation}

We next investigated the effect of miR-146a on regulating TNF- $\alpha$-induced MUC5AC expression. To this end, $16 \mathrm{HBE}$ cells were treated with TNF- $\alpha$ in the presence or absence of miR-146a mimics, and cell viability and apoptosis were assessed using CCK-8 assay and flow cytometry, respectively. The results from CCK- 8 assay showed that miR-146a significantly increased cell viability in $16 \mathrm{HBE}$ cells treated with TNF- $\alpha$ (Figure 3A). Figure 3B,C showed that miR-146a effectively inhibited TNF- $\alpha$-induced cell apoptosis. Furthermore, MUC5AC level was assessed on both mRNA and protein in TNF- $\alpha$-treated $16 \mathrm{HBE}$ cells in the presence or absence of miR-146a. The qPCR analysis demonstrated that miR-146a markedly up-regulated the mRNA expression of MUC5AC compared with the miRcont (Figure 3D). Similarly, the result of western blot showed that the protein levels of MUC5AC were boosted by miR-146a mimics treatment (Figure 3E, F).

Previous studies demonstrated that $\mathrm{p} 38 \mathrm{MAPK}$ signaling is correlated with MUC5AC expression in airway epithelial cell after TNF- $\alpha$ treatment (23). We thus investigated the association of miR-146a with $\mathrm{p} 38 \mathrm{MAPK}$ signaling activation. As shown in Figure 4A, TNF- $\alpha$ treatment resulted in a significant increase of p38MAPK activation, whereas miR-146a partially inhibited TNF- $\alpha$-induced p38MAPK activation. miR-146a did not affect the activation of NF- $\kappa B$ signaling in TNF- $\alpha$-treated $16 \mathrm{HBE}$ cells (Figure 4B). These results demonstrate that miR-146a partially blocked TNF- $\alpha$ induced MUC5AC expression, at least in part by repressing p38MAPK signaling activation.

\section{Discussion}

In the present study the role of miR-134 and miR-146a on repressing TNF- $\alpha$-induced airway mucus hypersecretion was revealed and its underlying mechanism was further verified. The current data demonstrate that (I) TNF- $\alpha$ treatment increased MUC5AC expression, and repressed miR-134 and miR-146a expression in 16HBE cells; (II) miR-134 blocked TNF- $\alpha$-induced MUC5AC expression by repressing NF- $\mathrm{KB}$ activation; (III) miR-146a blocked TNF$\alpha$-induced MUC5AC expression by repressing p38MAPK activation. These data uncovered the important role of miR-134 and miR-146a in regulating mucus hypersecretion by regulating NF- $\mathrm{NB}$ and $\mathrm{p} 38 \mathrm{MAPK}$, and may provide a therapeutic opportunity for patients with airway mucus hypersecretion.

COPD is chronic pulmonary disorder, characterized by persistent inflammatory response to inhaling cigarette smoke (26). Bronchial epithelial cells and macrophages are mainly responsible for chronic inflammatory response (26). These cells could discharge proteases which lead to elastin degradation and emphysema, and thus facilitate inflammatory response $(27,28)$. Epithelial cells also release TGF- $\beta$ to induce tissue remodeling (29). Based on these facts, we established a cell model of mucus hypersecretion using the human bronchial epithelial cells (16HBE) by $\mathrm{TNF}-\alpha$ treatment. As expected, TNF- $\alpha$ treatment increased the mRNA and protein level of MUC5AC in 16HBE cells 
A

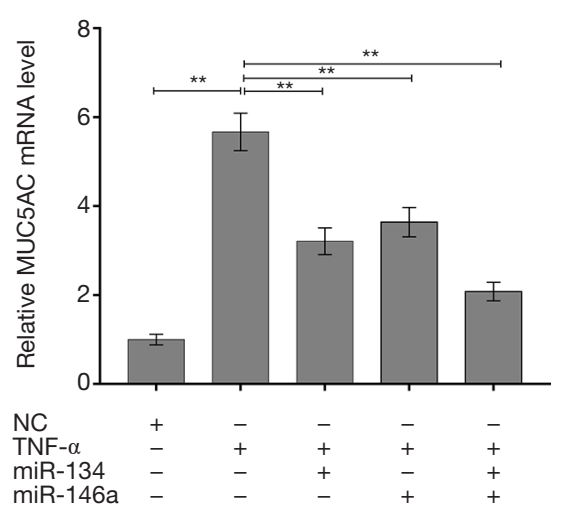

C

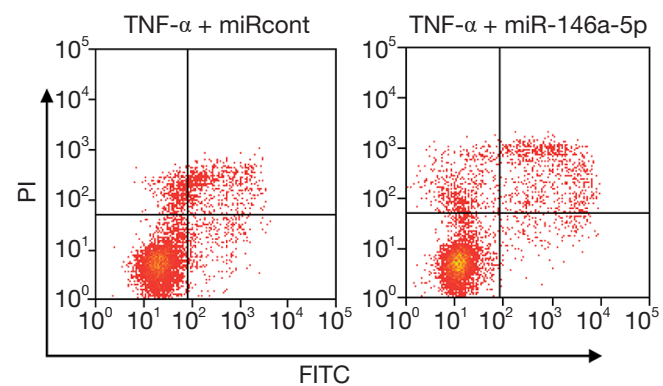

$\mathrm{E}$
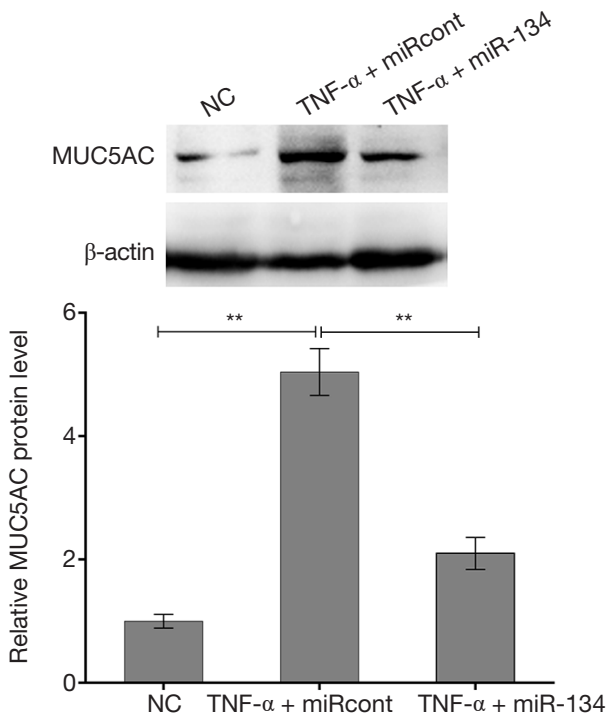

B

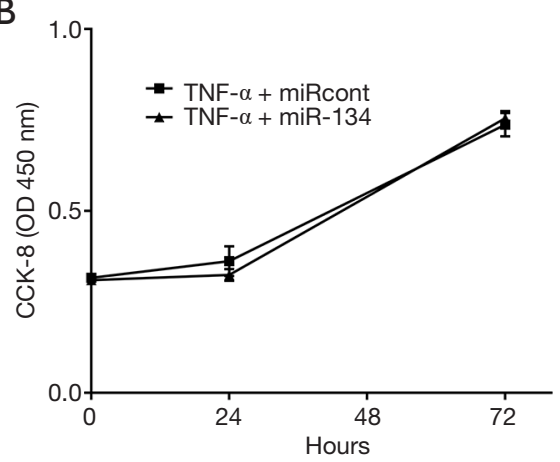

D

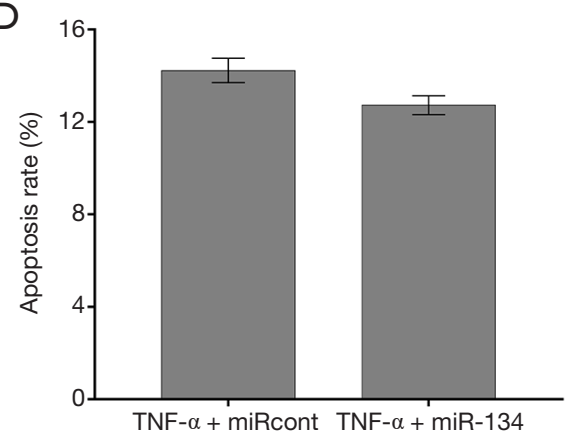

$\mathrm{F}$
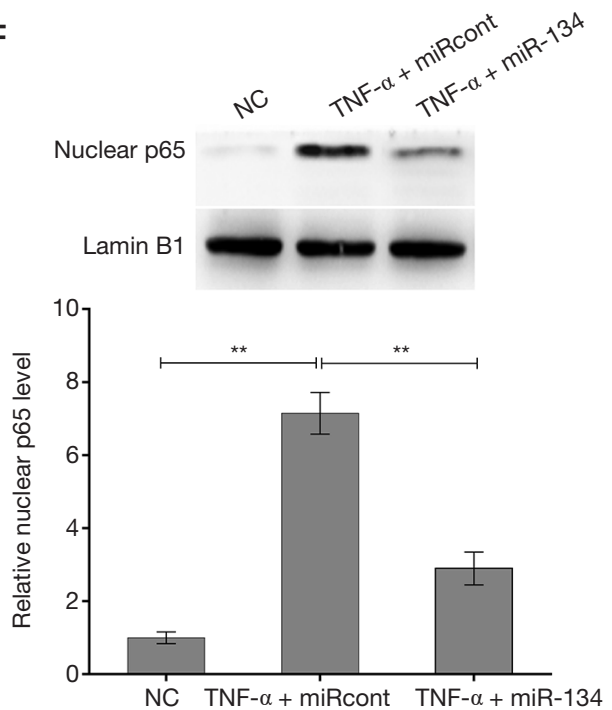

Figure 2 miR-134 blocked TNF- $\alpha$-induced MUC5AC expression by repressing NF- $\kappa B$ activation. (A) The mRNA level of MUC5AC was assessed using qPCR analysis in TNF- $\alpha$-treated 16HBE cells in the presence or absence of miR-134 or/and miR-146a. The characters "+" and "-" indicate the presence and absence of indicated reagents, respectively. (B) Cell viability was assessed using CCK-8 assay in TNF$\alpha$-treated 16HBE cells in the presence or absence of miR-134. (C,D) Cell apoptosis was assessed using flow cytometry in TNF- $\alpha$-treated $16 \mathrm{HBE}$ cells in the presence or absence of miR-134. (E) The protein expression of MUC5AC was assessed using western blot analysis in TNF- $\alpha$-treated 16HBE cells in the presence or absence of miR-134. (F) The protein expression of nuclear p65 was assessed using western blot analysis in TNF- $\alpha$-treated 16HBE cells in the presence or absence of miR-134. Lamin B1 was used to an internal control. ${ }^{* *}, \mathrm{P}<0.01$. 
A

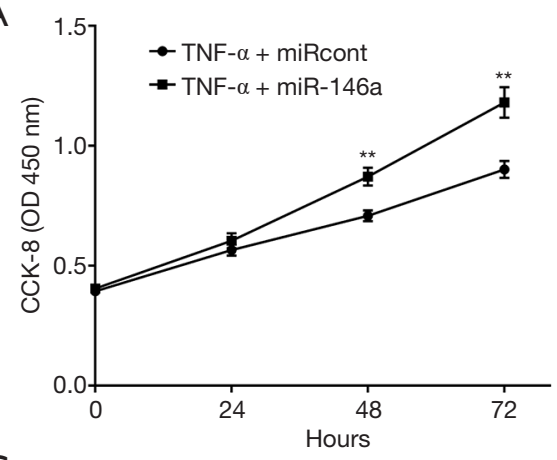

C

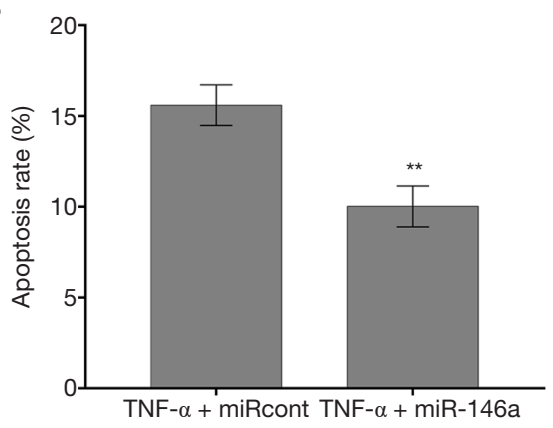

E

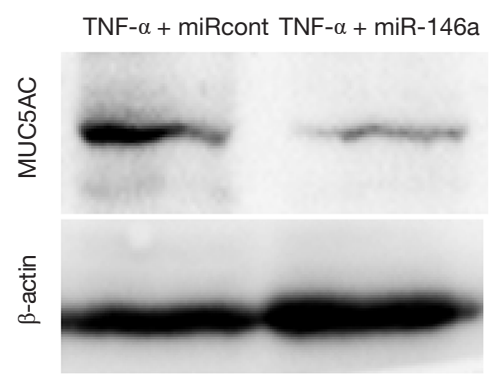

B
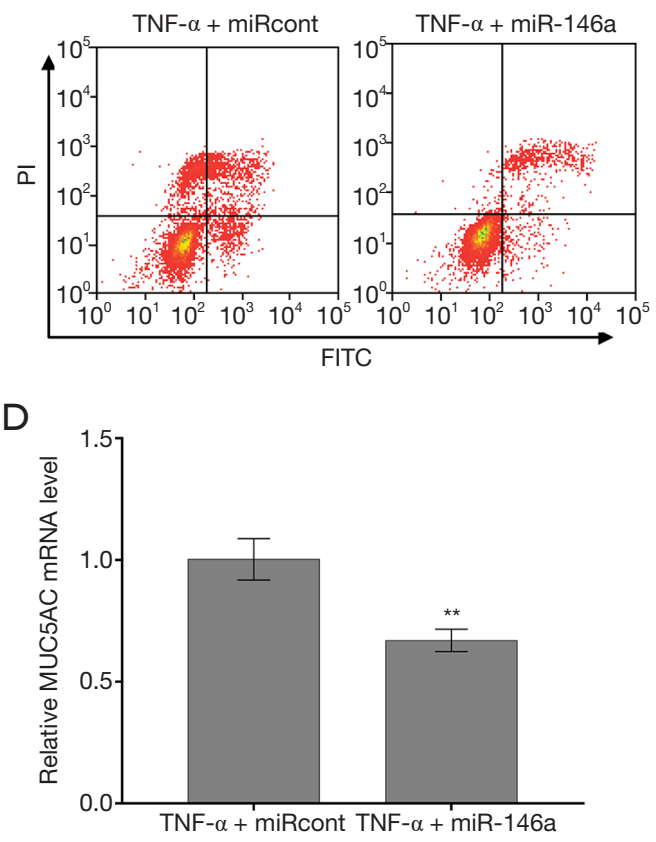

$\mathrm{F}$

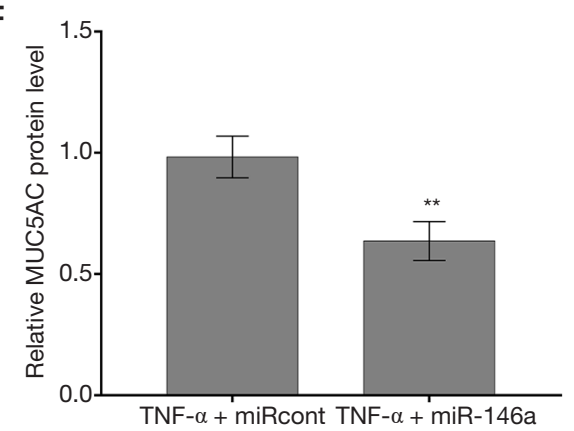

Figure 3 miR-146a blocked TNF- $\alpha$-induced MUC5AC expression. (A) Cell viability was assessed using CCK- 8 assay in TNF- $\alpha$-treated $16 \mathrm{HBE}$ cells in the presence or absence of miR-146a. (B,C) Cell apoptosis was assessed using flow cytometry in TNF- $\alpha$-treated 16HBE cells in the presence or absence of miR-146a. (D) The mRNA expression of MUC5AC was assessed using qPCR analysis in TNF- $\alpha$-treated $16 \mathrm{HBE}$ cells in the presence or absence of miR-146a. (E,F) The protein expression of MUC5AC was assessed using western blot analysis in TNF- $\alpha$-treated $16 \mathrm{HBE}$ cells in the presence or absence of miR-146a. ${ }^{* *}, \mathrm{P}<0.01$.

through qPCR and western blot analysis.

The pathological role of miRNAs in COPD has been verified in many studies, in which aberrant miRNAs expression has been revealed in lung cell or airway epithelial cell $(30,31)$. Cao et al., showed that the miR183 level is upregulated in patients with COPD, and miR183 is associated with the severity of COPD through repressing $\mathrm{Ca}^{2+}$-activated $\mathrm{K}^{+}$channels $\beta 1$ subunit (BKCa $\beta 1$ ) expression (32). Additionally, the plasma levels of miR133, miR-499, and miR-206 are increased in COPD patients compared to the healthy controls (33). On the contrary, several miRNAs are downregulated in COPD patients such as miR-134, miR-146a, miR-500a, and miR-1207 (12). The miR-146a level is further decreased in COPD fibroblasts after cytokine (IL-1 $\beta$, or TNF- $\alpha$ ) treatment (19). In the study, we assessed the effect of $\mathrm{TNF}-\alpha$ on regulating miR-146a expression in airway epithelial cell, and data showed that the expression of miR-146a is decreased in $16 \mathrm{HBE}$ cells following TNF- $\alpha$ treatment. miR-146a contributes to alleviate TNF- $\alpha$ - 
A
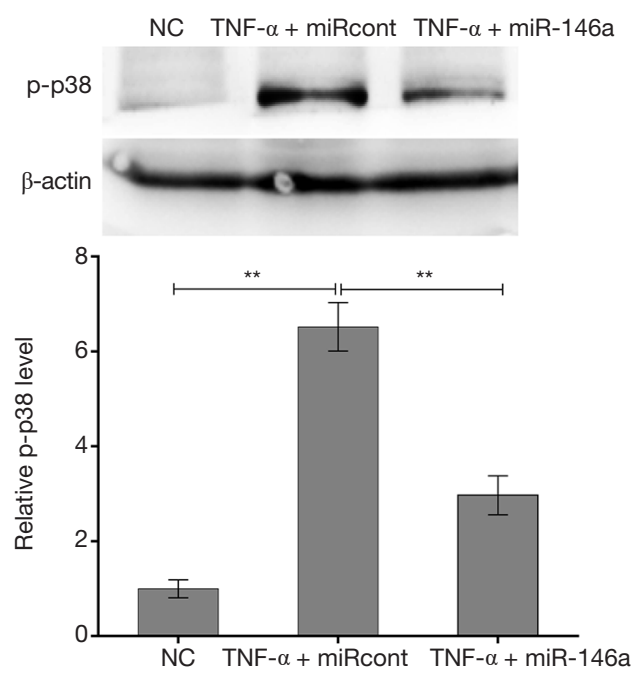

B
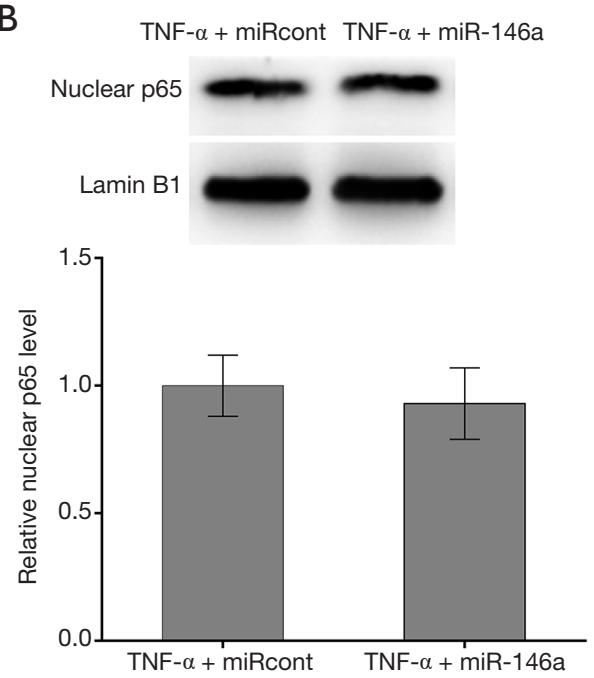

Figure 4 miR-146a repressed TNF- $\alpha$-induced p38MAPK activation. (A) The phosphorylated p38 (p-p38) protein expression was assessed using western blot analysis in TNF- $\alpha$-treated $16 \mathrm{HBE}$ cells in the presence or absence of miR-146a. $\beta$-actin was used to an internal control. (B) The protein expression of nuclear p 65 was assessed using western blot analysis in TNF- $\alpha$-treated 16HBE cells in the presence or absence of miR-146a. Lamin B1 was used to an internal control. **, $\mathrm{P}<0.01$.

induced increase of MUC5AC. Although previous studies have demonstrated the negative association of miR-146a with NF- $\kappa B$ activation in small intestine ischemia (34) and cancer cells (35), the current results did not observe the effect of miR-146a on regulating NF- $\kappa B$ activation in airway epithelial cells. Our data revealed that TNF- $\alpha$ results in an increase of $\mathrm{p} 38 \mathrm{MAPK}$ activation, whereas miR-146a partially inhibited TNF- $\alpha$-induced p38MAPK activation, indicating that miR-146a blocks TNF$\alpha$-induced MUC5AC expression, at least in part by repressing $\mathrm{p} 38 \mathrm{MAPK}$ signaling activation.

miR-134 is the strongest decreased miRNA in mild COPD patients with chronic mucus hypersecretion (12), but the potential function of miR-134 on mucus hypersecretion remains unknown. In the study, we found that the expression of miR-134 is decreased significantly in $16 \mathrm{HBE}$ cells after TNF- $\alpha$ treatment. More important, forced expression of miR-134 inhibits TNF- $\alpha$-induced MUC5AC expression although miR-134 did not affect TNF- $\alpha$-regulated $16 \mathrm{HBE}$ cells viability and apoptosis. Mechanistically, miR-134 represses TNF- $\alpha$-induced NF$\kappa \mathrm{B}$ activation, indicating that miR-134 blocks TNFa-induced MUC5AC expression, at least in part by repressing $\mathrm{NF}-\kappa \mathrm{B}$ activation.

The limitations of the present study lie in the following aspects: (I) the direct target gene of miR-134 in regulating
NF-кB signaling in airway epithelial cells could not be identified; (II) the direct target gene of miR-146a in regulating p38 signaling in airway epithelial cells could not be identified; (III) the effect of miR-134 and miR-146a on repressing cytokines-induced mucin hypersecretion has not been verified in vivo.

\section{Conclusions}

In conclusion, the current data demonstrated that both miR-134-5p and miR-146a-5p conferred protection against TNF- $\alpha$-induced mucus hypersecretion through repressing NF- $\kappa B$ and $\mathrm{p} 38$ MAPK signaling, indicated that miR-134$5 \mathrm{p}$ and miR-146a-5p may provide a therapeutic opportunity for patients with airway mucus hypersecretion.

\section{Acknowledgments}

Funding: This work was supported by the National Natural Science Foundation of China (No. 81704025).

\section{Footnote}

Reporting Checklist: The authors have completed the MDAR checklist. Available at https://dx.doi.org/10.21037/ tcr-20-3375 
Data Sharing Statement: Available at https://dx.doi. org/10.21037/tcr-20-3375

Peer Review File: Available at https://dx.doi.org/10.21037/ tcr-20-3375

Conflicts of Interest: All authors have completed the ICMJE uniform disclosure form (available at https://dx.doi. org/10.21037/tcr-20-3375). All authors report this work was supported by the National Natural Science Foundation of China (No. 81704025). The authors have no other conflicts of interest to declare.

Ethical Statement: The authors are accountable for all aspects of the work in ensuring that questions related to the accuracy or integrity of any part of the work are appropriately investigated and resolved. The study was conducted in accordance with the Declaration of Helsinki (as revised in 2013). Institutional ethical approval and informed consent were waived.

Open Access Statement: This is an Open Access article distributed in accordance with the Creative Commons Attribution-NonCommercial-NoDerivs 4.0 International License (CC BY-NC-ND 4.0), which permits the noncommercial replication and distribution of the article with the strict proviso that no changes or edits are made and the original work is properly cited (including links to both the formal publication through the relevant DOI and the license). See: https://creativecommons.org/licenses/by-nc-nd/4.0/.

\section{References}

1. Ko FW, Chan KP, Hui DS, et al. Acute exacerbation of COPD. Respirology 2016;21:1152-65.

2. Barnes PJ, Burney PG, Silverman EK, et al. Chronic obstructive pulmonary disease. Nat Rev Dis Primers 2015;1:15076.

3. Kirkham PA, Barnes PJ. Oxidative stress in COPD. Chest 2013;144:266-73.

4. Wang Y, Xu J, Meng Y, et al. Role of inflammatory cells in airway remodeling in COPD. Int J Chron Obstruct Pulmon Dis 2018;13:3341-8.

5. Chambers E, Rounds S, Lu Q. Pulmonary Endothelial Cell Apoptosis in Emphysema and Acute Lung Injury. Adv Anat Embryol Cell Biol 2018;228:63-86.

6. Zhang J, Zheng J, Huang K, et al. Use of glucocorticoids in patients with COPD exacerbations in China: a retrospective observational study. Ther Adv Respir Dis 2018;12:1753466618769514.

7. Corrao S, Brunori G, Lupo U, et al. Effectiveness and safety of concurrent beta-blockers and inhaled bronchodilators in COPD with cardiovascular comorbidities. Eur Respir Rev 2017;26:160123.

8. Fahy JV, Dickey BF. Airway mucus function and dysfunction. N Engl J Med 2010;363:2233-47.

9. Kato K, Chang EH, Chen Y, et al. MUC1 contributes to goblet cell metaplasia and MUC5AC expression in response to cigarette smoke in vivo. Am J Physiol Lung Cell Mol Physiol 2020;319:L82-90.

10. Mohr AM, Mott JL. Overview of microRNA biology. Semin Liver Dis 2015;35:3-11.

11. Piletic K, Kunej T. MicroRNA epigenetic signatures in human disease. Arch Toxicol 2016;90:2405-19.

12. Tasena H, Faiz A, Timens W, et al. microRNAmRNA regulatory networks underlying chronic mucus hypersecretion in COPD. Eur Respir J 2018;52:1701556.

13. Alipoor SD, Adcock IM, Garssen J, et al. The roles of miRNAs as potential biomarkers in lung diseases. Eur $\mathbf{J}$ Pharmacol 2016;791:395-404.

14. Ezzie ME, Crawford M, Cho JH, et al. Gene expression networks in COPD: microRNA and mRNA regulation. Thorax 2012;67:122-31.

15. Tang K, Zhao J, Xie J, et al. Decreased miR-29b expression is associated with airway inflammation in chronic obstructive pulmonary disease. Am J Physiol Lung Cell Mol Physiol 2019;316:L621-9.

16. Peng L, Han L, Li XN, et al. The Predictive Value of microRNA-134 and microRNA-1233 for the Early Diagnosis of Acute Exacerbation of Chronic Obstructive Pulmonary Disease with Acute Pulmonary Embolism. Int J Chron Obstruct Pulmon Dis 2020;15:2495-503.

17. Osei ET, Florez-Sampedro L, Tasena H, et al. miR$146 a-5 p$ plays an essential role in the aberrant epithelial-fibroblast cross-talk in COPD. Eur Respir J 2017;49:1602538.

18. Li N, Li S, Wu Y, et al. Dexmedetomidine targets miR-146a and participates in the progress of chronic obstructive pulmonary disease in vivo and in vitro. Genes Genomics 2021. doi: 10.1007/s13258-020-01019-2. [Epub ahead of print].

19. Sato T, Liu X, Nelson A, et al. Reduced miR-146a increases prostaglandin $\mathrm{E}(2)$ in chronic obstructive pulmonary disease fibroblasts. Am J Respir Crit Care Med 2010;182:1020-9.

20. Sikder MA, Lee HJ, Mia MZ, et al. Inhibition of TNF- 
alpha-induced MUC5AC mucin gene expression and production by wogonin through the inactivation of NFkappaB signaling in airway epithelial cells. Phytother Res 2014;28:62-8.

21. Busse PJ, Zhang TF, Srivastava K, et al. Chronic exposure to TNF-alpha increases airway mucus gene expression in vivo. J Allergy Clin Immunol 2005;116:1256-63.

22. Zhu Z, Homer RJ, Wang Z, et al. Pulmonary expression of interleukin-13 causes inflammation, mucus hypersecretion, subepithelial fibrosis, physiologic abnormalities, and eotaxin production. J Clin Invest 1999;103:779-88.

23. Song KS, Lee WJ, Chung KC, et al. Interleukin-1 beta and tumor necrosis factor-alpha induce MUC5AC overexpression through a mechanism involving ERK/ p38 mitogen-activated protein kinases-MSK1-CREB activation in human airway epithelial cells. J Biol Chem 2003;278:23243-50.

24. Hauber HP, Daigneault P, Frenkiel S, et al. Niflumic acid and MSI-2216 reduce TNF-alpha-induced mucin expression in human airway mucosa. J Allergy Clin Immunol 2005;115:266-71.

25. Zhou Y, Xu X, Wu J, et al. Allyl isothiocyanate treatment alleviates chronic obstructive pulmonary disease through the Nrf2-Notch1 signaling and upregulation of MRP1. Life Sci 2020;243:117291.

26. Aghasafari P, George U, Pidaparti R. A review of inflammatory mechanism in airway diseases. Inflamm Res 2019;68:59-74.

27. Suki B, Lutchen KR, Ingenito EP. On the progressive

Cite this article as: Fu HT, Zhang Y, Zhang P, Wu H, Sun XQ, Shen SY, Dou DB. Tumor necrosis factor- $\alpha$ promotes airway mucus hypersecretion by repressing miR-146a-5p and miR-134-5p levels in human airway epithelial cells. Transl Cancer Res 2021;10(9):4047-4056. doi: 10.21037/tcr-20-3375 nature of emphysema: roles of proteases, inflammation, and mechanical forces. Am J Respir Crit Care Med 2003;168:516-21.

28. Lane N, Robins RA, Corne J, et al. Regulation in chronic obstructive pulmonary disease: the role of regulatory T-cells and Th17 cells. Clin Sci (Lond) 2010;119:75-86.

29. Barnes PJ. Immunology of asthma and chronic obstructive pulmonary disease. Nat Rev Immunol 2008;8:183-92.

30. Szymczak I, Wieczfinska J, Pawliczak R. Molecular Background of miRNA Role in Asthma and COPD: An Updated Insight. Biomed Res Int 2016;2016:7802521.

31. Stolzenburg LR, Harris A. The role of microRNAs in chronic respiratory disease: recent insights. Biol Chem 2018;399:219-34.

32. Cao Z, Zhang N, Lou T, et al. microRNA-183 downregulates the expression of BKCabeta 1 protein that is related to the severity of chronic obstructive pulmonary disease. Hippokratia 2014;18:328-32.

33. Donaldson A, Natanek SA, Lewis A, et al. Increased skeletal muscle-specific microRNA in the blood of patients with COPD. Thorax 2013;68:1140-9.

34. He X, Zheng Y, Liu S, et al. MiR-146a protects small intestine against ischemia/reperfusion injury by downregulating TLR4/TRAF6/NF-kappaB pathway. J Cell Physiol 2018;233:2476-88.

35. Meng Q, Liang C, Hua J, et al. A miR-146a-5p/ TRAF6/NF-kB p65 axis regulates pancreatic cancer chemoresistance: functional validation and clinical significance. Theranostics 2020;10:3967-79. 


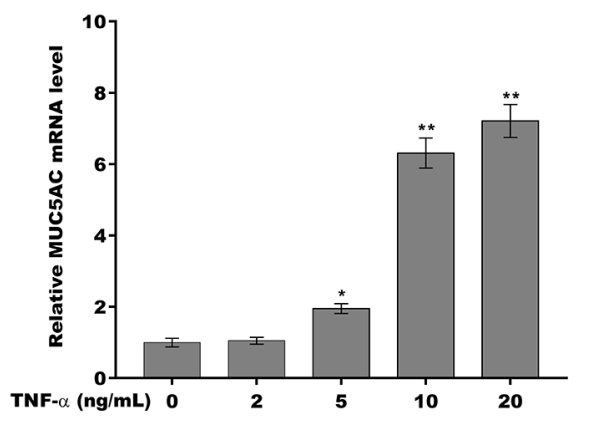

Figure S1 The dose dependence of TNF- $\alpha$ on MUC5AC expression in 16HBE. 6HBE cells were treated with different dose of TNF- $\alpha(0,2$, 5,10 , and $20 \mathrm{ng} / \mathrm{mL}$ ) for $24 \mathrm{~h}$, and then the mRNA level of MUC5AC was assessed using qPCR analysis. *, $\mathrm{P}<0.05$; ** $\mathrm{P}<0.01$. 